\title{
Pengaruh Media Pembelajaran Berbasis Teknologi Informasi Dalam Proses Pembelajaran Kimia Terhadap Peningkatan Hasil Belajar Siswa
}

\author{
Nurchaili \\ Guru Kimia Madrasah Aliyah Negeri Darussalam Kabupaten Aceh Besar \\ e-mail: nurchaily@yahoo.com
}

\begin{abstract}
Abstrak: Tujuan penelitian ini dimaksudkan untuk mengetahui ada tidaknya pengaruh penggunaan media pembelajaran berbasis TI dalam proses pembelajaran kimia terhadap peningkatan hasil belajar siswa. Penelitian ini menggunakan metode kuantitatif eksplanasi eksperimen. Sampel penelitian sebanyak 184 siswa yang dikelompokkan ke dalam kelompok eksperimen dan kelompok kontrol berdasarkan pola kelompok paralel yang ekuivalen. Instrumen yang digunakan adalah tes. Hasil penelitian menunnjukkan bahwa nilai rata-rata hasil belajar kimia berbasis TI sebesar 89,06 dengan standar deviasi 4,748, sedangkan nilai rata-rata hasil belajar kimia secara konvensional 62,05 dengan standar deviasi 13,133. Rata-rata kedua kelompok ini diuji secara statistik menggunakan statistik tes pada signifikansi $(\alpha=5 \%)$ untuk mengetahui ada tidaknya perbedaaan. Dari hasil uji diperoleh nilai t hitung $(18,552)$ lebih besar dari t tabel $(1,986)$ dengan signifikansi 0,000 maka dapat disimpulkan kedua rata-rata hasil belajar berbeda signifikan (nyata). Dengan demikian berarti bahwa media pembelajaran berbasis TI dapat digunakan dalam proses pembelajaran, khususnya kimia, guna meningkatkan hasil belajar siswa.
\end{abstract}

Kata kunci: media pembelajaran, TI, dan pembelajaran kimia dan hasil belajar.

\begin{abstract}
The purpose of this study is to determine whether there is any effect of the using learning media based IT in the chemicals learning processs to the improvement of student learning outcomes. This study used quantitative explanation of experiment. The total samples of this research are 184 students which are grouped into experimental groups and control groups based on the pattern of the equivalent parallel groups. The instrument used is a matter of testing. The results were obtained an average rating of information technology-based chemistry learning outcomes of 89.06 with a standard deviation of 4.748 , while the average value of learning outcomes in the conventional chemical is 62.05 with a standard deviation of 13.133. Both of the two groups average value was statistically tested using t statistics test on the significance test $(\alpha=5 \%)$ to determine whether there is a difference. From the test results obtained $t$ value $(18.552)$ is bigger than $t$ table (1.986) with significance 0.000 . So, it can be concluded both average learning outcomes differ significantly. It can be concluded that learning media based information technology (IT) can be used in the learning process, particularly chemicals, in order to improve student learning outcomes.
\end{abstract}

Key words: learning media, information technology, chemistry learning and learning outcomes.

\section{Pendahuluan}

Pendidikan mempunyai peranan yang sangat strategis dalam mempersiapkan generasi penerus yang memiliki pengetahuan dan kecerdasan yang tinggi serta menguasai berbagai keahlian yang kompeten. Pendidikan merupakan jembatan penghubung dalam mengantarkan kita pada tatanan masyarakat pembelajar (learning society) yang terus belajar dari waktu ke waktu sehingga tercapai suatu acuan dasar yang dapat mere- fleksikan tugas mulia pendidikan dalam meningkatkan taraf hidup suatu bangsa (Ma'arif, dkk., 1991: 8).

Sistem pendidikan harus peka terhadap dinamika kehidupan berbangsa yang kini menuntut perubahan di berbagai bidang, serta dinamika dari perubahan dunia yang dikenal sebagai gelombang globalisasi. Pendidikan di abad pengetahuan menuntut adanya manajemen pendidikan yang modern dan profesional dengan bernuansa pada 
pemanfaatan teknologi. Dengan menggandeng kemajuan teknologi informasi (TI) diharapkan pendidikan akan menjadi lebih baik serta fleksibel, baik dalam sistem yang hendak dikembangkan, materi yang dapat diakses siswa dan guru, media pembelajaran atau media instruksional dan proses pembelajaran yang akan diterapkan serta bagaimana mencari alternatif solusi bila ditemukan hambatan dari siswa dan guru atau penyelenggara pendidikan.

Penerapan TI di bidang pendidikan, khususnya dalam proses pembelajaran diyakini dapat memberikan perubahan yang signifikan dalam meningkatkan kualitas pendidikan. Berdasarkan opini ini, penulis sangat tertarik untuk mengkaji lebih jauh dan mendalam mengenai pengaruh penggunaan media pembelajaran berbasis TI dalam proses pembelajaran terhadap peningkatan hasil belajar siswa.

Menurut Nugroho (2005), ada beberapa permasalahan yang dihadapi sekolah menengah di Indonesia dalam memanfaatkan TI sebagai media pembelajaran antara lain a) Media pembelajaran berbasis TI membutuhkan dana yang cukup besar baik untuk pengadaan maupun pemeliharaannya; b) Belum mendukungnya fasilitas/sarana-prasarana/infrastruktur seperti listrik; c) Masih kurangnya guru dan sumber daya pengajar yang berkompeten dalam memanfaatkan TI sebagai media pembelajaran; dan d) Sumber informasi dan referensi yang masih sangat kurang.

Permasalahan dalam penggunaan media pembelajaran berbasis TI untuk proses pembelajaran ini juga dihadapi oleh Madrasah Aliyah Negeri (MAN) Darussalam, Kabupaten Aceh Besar, Provinsi Nanggroe Aceh Darussalam, yang merupakan salah satu provinsi yang terletak di ujung Barat wilayah Negara Kesatuan Republik Indonesia.

MAN Darussalam telah dilengkapi dengan laboratorium komputer yang memiliki 41 unit komputer, yang sebelumnya hanya 1 unit komputer. Tersedianya sebuah laboratorium komputer di MAN Darussalam mendatangkan permasalahan baru yang berkaitan dengan penggunaan komputer sebagai media pembelajaran berbasis TI di antaranya: a) Adanya anggapan bahwa komputer hanya digunakan untuk mata pelajaran komputer saja; b) Kurang- nya pemahaman dan pengetahuan tentang manfaat komputer sebagai media pembelajaran; c) Belum tersedianya materi pembelajaran interaktif yang sesuai dengan kebutuhan setiap mata pelajaran; d) Sulitnya mendapatkan materi pembelajaran interaktif dalam Bahasa Indonesia; e) Kurangnya sosialisasi penggunaan media pembelajaran berbasis TI sehingga banyak guru yang belum mengetahui manfaat penggunaan media pembelajaran berbasis TI; dan f) Kurangnya pendidikan dan pelatihan bagi guru dalam memanfaatkan media pembelajaran berbasis TI.

Pada prinsipnya permasalahan penggunaan media pembelajaran berbasis TI di MAN Darussalam adalah kurangnya pemahaman dan wawasan terhadap manfaat media pembelajaran berbasis TI. Untuk dapat meningkatkan pemahaman dan wawasan mengenai manfaat penggunaan media pembelajaran berbasis TI maka diperlukan penelitian guna mengetahui pengaruh penggunaan media pembelajaran berbasis TI dalam proses pembelajaran terhadap peningkatan hasil belajar siswa. Masalah penelitian berikut ini dibatasi oleh beberapa hal, yaitu: a) lingkup masalah penelitian ini hanya dibatasi pada masalah penggunaan media pembelajaran berbasis TI dalam proses pembelajaran kimia terhadap peningkatan hasil belajar siswa; dan b) hasil belajar siswa yang dimaksud pada penelitian ini dibatasi pada ranah kognitif (pengetahuan) saja.

Berdasarkan penjelasan di atas maka masalah penelitian ini adalah untuk mengetahui "Apakah penggunaan media pembelajaran berbasis TI dalam proses pembelajaran kimia berpengaruh terhadap peningkatan hasil belajar siswa?". Untuk dapat menjawab permasalahan di atas, masalah penelitian ini dirumuskan secara rinci sebagai berikut: Adakah perbedaan hasil belajar siswa yang menggunakan media pembelajaran berbasis TI dalam proses pembelajaran kimia dengan hasil belajar siswa pada proses pembelajaran kimia secara konvensional? Dengan rumusan hipotesisnya: $\left(\mathrm{H}_{0}\right)$ : Tidak ada perbedaan hasil belajar siswa yang menggunakan media pembelajaran berbasis TI dalam proses pembelajaran dengan hasil belajar siswa pada proses pembelajaran secara konvensional; dan $\left(\mathrm{H}_{1}\right)$ : Ada perbedaan hasil belajar siswa yang 
menggunakan media pembelajaran berbasis TI dalam proses pembelajaran dengan hasil belajar siswa pada proses pembelajaran secara konvensional.

Penelitian ini bertujuan untuk mengetahui ada tidaknya pengaruh penggunaan media pembelajaran berbasis TI dalam proses pembelajaran kimia terhadap peningkatan hasil belajar siswa. Penelitian ini bermanfaat baik secara teoritis maupun praktis. Disebut manfaat teoritis karena menjadi sumbangan guna memperluas wawasan dalam kajian TI khususnya dalam proses pembelajaran dan menambah referensi yang dapat dijadikan bahan rujukan untuk pengembangan penelitian lebih lanjut. Sedangkan manfaat praktis antara lain dapat menjadi bukti empirik yang memberikan suatu gambaran menyeluruh tentang pengaruh penggunaan media pembelajaran berbasis TI dalam proses pembelajaran, khususnya mata pelajaran kimia. Di samping itu, dapat meningkatkan wawasan serta pemahaman guru mengenai pemanfaatan media pembelajaran berbasis TI dan sekaligus menghapus anggapan bahwa media pembelajaran berbasis TI hanyalah untuk mata pelajaran komputer. Selanjutnya memotivasi guru guna meningkatkan kompetensinya dalam menggunakan media pembelajaran berbasis TI secara optimal dalam proses pembelajaran. Manfaat lain dari hasil penelitian ini diharapkan dapat menjadi bahan pemikiran dan pertimbangan bagi pihak terkait dalam pengambilan keputusan untuk menerapkan suatu kebijakan.

\section{Kajian Literatur}

Memasuki era globalisasi yang diikuti dengan adanya perkembangan Teknologi Informasi (TI) yang berjalan dengan sangat pesat, menuntut kebijakan semua pihak untuk menyikapinya. Terutama sekali dunia pendidikan, kehadiran TI tidak memberikan pilihan lain kepada dunia pendidikan selain turut serta dalam memanfaatkannya (http://lib.balaibahasa.org//view deetailphp?id=8975)

\section{Pembelajaran Konvensional dan Pembe- lajaran Berbasis TI}

Pembelajaran konvensional merupakan model pembelajaran yang lebih berpusat pada guru (teacher centered). Sudjana (2001:39) menyatakan bahwa kegiatan pembelajaran yang berpusat pada guru menekankan pentingnya aktivitas guru dalam membelajarkan siswa. Siswa berperan sebagai pengikut dan penerima pasif dari kegiatan pembelajaran yang dilaksanakan.

Pembelajaran berbasis TI merupakan proses pembelajaran yang menggunakan berbagai teknologi informasi sebagai media pembelajaran. Dalam pembelajaran berbasis TI, peran guru sebagai the sole authority of knowledge berubah menjadi fasilitator bagi siswa untuk berinteraksi dengan berbagai sumber belajar (http://lib. balaibahasa.org//viewdeetailphp?id=8975).

\section{Media Dalam Proses Pembelajaran}

Menurut Pribadi (2004:146) media pembelajaran adalah sesuatu yang dapat membawa informasi dan pesan dari pengirim atau sumber informasi kepada penerima atau learner. Media pembelajaran adalah suatu alat yang berfungsi untuk menyampaikan pesan pembelajaran. Semakin banyak tujuan pembelajaran yang bisa dicapai dengan bantuan media pembelajaran maka semakin baiklah media itu.

Ena (2000:3) mengajukan enam kriteria untuk menilai media pembelajaran interaktif, yaitu a) Kemudahan navigasi, sebuah program harus dirancang sesederhana mungkin sehingga siswa tidak perlu belajar komputer lebih dahulu untuk dapat menggunakannya sebagai media pembelajaran interaktif; b) Kandungan kognisi, pembelajaran interaktif harus mengandung kognisi atau pengetahuan yang sesuai dengan tujuan pembelajaran yang diharapkan; c) Pengetahuan dan presentasi informasi, pengetahuan atau informasi harus disampaikan dan dipresentasikan secara benar; d) Integrasi media, media harus dirancang sedemikian rupa sehingga dapat mengintegrasikan aspek dan keterampilan yang harus dipelajari siswa; e) Estetika, untuk menarik minat siswa, pembelajaran interaktif harus mempunyai tampilan yang artistik. Oleh karenanya estetika juga merupakan sebuah kriteria yang harus mendapat perhatian penting; dan f) Fungsi secara keseluruhan, program pembelajaran interaktif yang dikembangkan harus memberikan pembelajaran yang diinginkan oleh siswa, sehingga pada waktu siswa selesai men- 
jalankan sebuah program siswa merasa telah belajar sesuatu.

\section{Media Pembelajaran Berbasis TI}

Salah satu jenis teknologi yang memiliki potensi besar untuk digunakan sebagai media pembelajaran berbasis TI adalah pemanfaatan teknologi komputer. Teknologi komputer dengan kemampuan interaktifnya yang tinggi dapat dijadikan sebagai sarana penyampaian informasi dan ilmu pengetahuan serta sebagai sarana untuk memperoleh umpan balik bagi siswa.

Penggunaan komputer sebagai media pembelajaran interaktif dapat diwujudkan dalam berbagai bentuk program Computer-Assisted Learning ( $C A L)$, surat elektronik, dan komputer multimedia yang dapat digunakan sebagai sarana pembelajaran baik untuk individual maupun kelompok. Pemanfaatan teknologi komputer dalam proses pembelajaran berbasis TI juga memiliki kekurangan dan keterbatasan di samping sederet kelebihan dan keunggulannya sebagaimana diuraikan berikut ini.

Pribadi (2004:148) mengemukakan sejumlah kelebihan dan juga kelemahan yang ada pada media komputer. Komputer sebagai media pembelajaran memberikan delapan keuntungan, yaitu: 1) Komputer memungkinkan siswa belajar sesuai dengan kemampuan dan kecepatannya dalam memahami pengetahuan dan informasi yang ditayangkan; 2) Penggunaan komputer dalam proses pembelajaran membuat siswa dapat melakukan kontrol terhadap aktivitas belajarnya; 3) Komputer dapat menciptakan iklim belajar yang efektif bagi siswa yang lambat (slow learner), tetapi juga dapat memacu efektivitas belajar bagi siswa yang lebih cepat (fast learner); 4) Komputer dapat diprogram agar mampu memberikan umpan balik terhadap hasil belajar dan memberikan pengukuhan (reinforcement) terhadap prestasi belajar siswa; 5) Kemampuan komputer untuk merekam hasil belajar pemakainya (record keeping), komputer dapat diprogram untuk memeriksa dan memberikan skor hasil belajar secara otomatis; 6) Komputer dapat dirancang untuk memberikan preskripsi atau saran kepada siswa dalam melakukan kegiatan belajar tertentu. Kemampuan ini mengakibatkan komputer dapat dijadikan sebagai sarana untuk pembelajaran yang bersifat individual (individual learning); 7) Komputer memiliki kemampuan dalam mengintegrasikan komponen warna, suara dan animasi grafik (graphic animation) sehingga mampu menyampaikan informasi dan pengetahuan secara lebih nyata. Komputer dapat digunakan sebagai sarana untuk melakukan kegiatan belajar yang bersifat simulasi; dan 8) Penggunaan komputer dalam proses belajar dapat meningkatkan hasil belajar dengan waktu dan biaya yang relatif kecil. Contoh yang tepat adalah program komputer simulasi untuk melakukan percobaan pada mata pelajaran kimia. Penggunaan program simulasi dapat mengurangi biaya bahan dan peralatan untuk melakukan percobaan.

Ena (2000:3) menyatakan bahwa komputer sebagai sarana utama pembelajaran berbasis TI memiliki empat kelemahan, yaitu 1) Tingginya biaya pengadaan dan pengembangan program komputer, terutama yang dirancang khusus untuk maksud pembelajaran; 2) Pengadaan, pemeliharaan, dan perawatan komputer yang meliputi perangkat keras (hardware) dan perangkat lunak (software) memerlukan biaya yang relatif tinggi; 3) Masalah Iain adalah compatability dan incompability antara hardware dan software; dan 4) Kesulitan merancang dan memproduksi program pembelajaran berbasis komputer (computer based instruction).

Berbagai kalangan meyakini bahwa manfaat TI sebagai media dalam proses pembelajaran sangatlah besar. TI dianggap mampu menjadikan pembelajaran lebih efektif, efisien, dan meningkatkan kualitas hasil pembelajaran. TI sebagai media pembelajaran juga mampu memberikan siswa pengalaman yang banyak dan variatif. TI sangat bermanfaat untuk membangkitkan motivasi siswa dalam belajar karena media ini menyajikan banyak pengalaman yang menarik, bahkan pengalaman akan dunia di luar sekolah. Menurut Pannen (2003:2) TI adalah solusi bagi beragam masalah pendidikan. Secara khusus, pemanfaatan TI dalam pembelajaran dipercaya akan: (a) meningkatkan kualitas pembelajaran; (b) mengembangkan keterampilan TI (IT skills) yang diperlukan oleh siswa ketika bekerja dan dalam kehidupannya nanti; (c) memperluas akses terhadap pendidikan dan pembelajaran; (d) menjawab "the technological imperative" (keharusan berpartisipasi dalam 
TI); (e) mengurangi biaya pendidikan; dan (f) meningkatkan rasio biaya-manfaat dalam pendidikan (dalam http://lib.balaibahasa.org// viewdeetailphp? id=8975).

\section{Pembelajaran Kimia Berbasis TI}

Mata pelajaran kimia termasuk dalam mata pelajaran sains, yang dapat dibuat simulasinya dalam upaya untuk memahami dan meramalkan konsep-konsepnya secara lebih mudah. Pembelajaran kimia dengan menggunakan media pembelajaran berbasis TI juga sangat efektif dan efisien, selain dapat menampilkan sajian yang menarik dan nyata juga dapat menghemat biaya dalam proses pembelajaran. Efisiensi pada mata pelajaran kimia melalui pemanfaatan media pembelajaran berbasis TI (pembelajaran interaktif) sangatlah dirasakan. Hal ini dikarenakan pembelajaran kimia membutuhkan berbagai macam percobaan/eksperimen dalam pelaksanaan proses pembelajaran. Pembelajaran interaktif berupa program komputer simulasi untuk melakukan percobaan pada mata pelajaran kimia menjadi alternatif yang sangat tepat. Penggunaan program simulasi ini dapat mengurangi biaya bahan dan peralatan untuk melakukan percobaan.

Riyanto (2006:10) dan Hardjito (2004) mengungkapkan hasil-hasil penelitian yang mencerminkan revolusi dari sistem pendidikan yang berhasil memanfaatkan TI dalam menunjang proses pembelajaran, antara lain prestasi spektakuler yang ditunjukkan SMP Christopher Columbus di Union City, New Jersey. Dalam tempo dua tahun, angka putus sekolah maupun siswa absen menurun ke titik nol dan nilai ujian siswa meningkat hampir 3 kali lebih tinggi dari rata-rata sekolah di seluruh New Jersey. Sekolah Dasar River Oaks di Oaksville, Ontario, Kanada, setiap siswanya berkesempatan untuk berhubungan dengan seluruh jaringan komputer karena sekolah ini dibangun dengan visi khusus agar siswa dapat memasuki era informasi instan dengan penuh keyakinan. SMU Lester B. Pearson Kanada, memiliki 300 komputer untuk 1.200 siswa. Sekolah ini memiliki angka putus sekolah yang terendah di Kanada (4 persen dibandingkan rata-rata nasional sebesar 30 persen).

Pada tahun 1996 Center for Applied Special Technology (CAST), melakukan studi terhadap 500 siswa kelas lima dan enam sekolah dasar yang dimasukkan dalam dua kelompok yaitu kelompok eksperimen yang dalam kegiatan belajarnya dilengkapi dengan akses ke Internet dan kelompok kontrol. Setelah dua bulan kelompok eksperimen mendapat nilai yang lebih tinggi berdasarkan hasil tes akhir. Anne L. Rantie dan kawan-kawan di SMU 1 BPK Penabur Jakarta, juga melakukan sebuah studi eksperimen mengenai pemanfaatan TI untuk mendukung kegiatan belajar mengajar Bahasa Inggris pada tahun 1999. Siswa yang terlibat dalam eksperimen memperlihatkan peningkatan kemampuan yang signifikan dalam menulis dan membuat karangan dalam Bahasa Inggris.

\section{Metode Penelitian}

Metode yang digunakan dalam penelitian ini adalah metode kuantitatif eksplanasi eksperimen. Metode ini sangat efektif untuk pengumpulan data guna melakukan pengukuran pengaruh atau efektivitas suatu alat, media pada kondisi tertentu (Bungin, 2005:148).

Pada penelitian ini yang menjadi variabel adalah: media pembelajaran berbasis TI sebagai variabel bebas (independent variable) dan hasil belajar siswa sebagai variabel terikat (dependent variable). Adapun definisi operasional masingmasing variabel tersebut adalah: Media pembelajaran berbasis TI yang digunakan pada penelitian ini berupa komputer yang dilengkapi dengan modul pembelajaran kimia interaktif yang di-download dari www.e-dukasi.net. Hasil belajar siswa pada penelitian ini dibatasi hanya pada ranah kognitif. Hasil belajar siswa ini diperoleh dari data primer berupa nilai siswa yang diukur sesudah siswa melakukan proses pembelajaran.

Indikator yang digunakan untuk mengukur pengaruh penggunaan media pembelajaran berbasis TI adalah hasil belajar siswa, berupa: nilai tes setelah siswa melakukan proses pembelajaran konvensional dan nilai tes setelah siswa melakukan proses pembelajaran dengan media pembelajaran berbasis TI.

\section{Metode Pemilihan Sampel}

Sebagai populasi adalah semua siswa MAN Darussalam Tahun Pelajaran 2007/2008 sebanyak 292 siswa. Pemilihan sampel menggunakan 
probability sampling, di mana ukuran sampel berbasis pada besar (jumlah) populasi. Dalam penelitian ini sample terdiri dari 184 siswa.

\section{Metode Pengumpulan Data}

Secara garis besar metode pengumpulan data yang digunakan dalam penelitian ini menggunakan metode eksperimen dengan desain penelitian eksperimennya sebagai berikut:

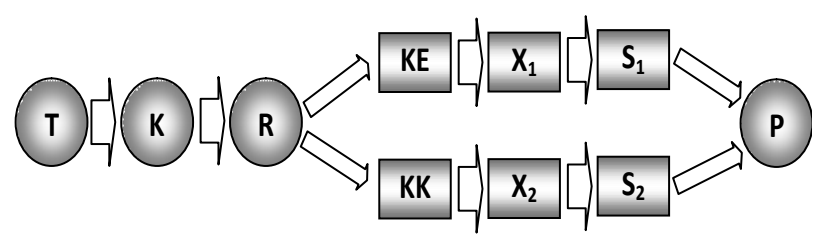

Gambar 1. Desain Penelitian Eksperimen

Keterangan:

$\mathrm{T}$ : Menetapkan tujuan eksperimen.

$\mathrm{K}$ : Menyiapkan kebutuhan eksperimen.

$\mathrm{R}$ : Menentukan kelompok secara randomisasi.

$\mathrm{KE}$ : Kelompok Eksperimen.

KK: Kelompok Kontrol.

$X_{1}$ : Perlakuan dengan proses pembelajaran menggunakan media pembelajaran berbasis TI.

$\mathrm{X}_{2}$ : Perlakuan dengan proses pembelajaran konvensional.

$\mathrm{S}_{1}$ : Tes untuk mengukur hasil belajar siswa pada proses pembelajaran kimia dengan menggunakan media pembelajaran berbasis TI.

$\mathrm{S}_{2}$ : Tes untuk mengukur hasil belajar siswa secara konvensional.

P : Pengolahan data.

\section{Teknik Analisis Data}

Setelah data terkumpul, selanjutnya dilakukan kegiatan analisis data. Menurut Bungin (2005:165) kegiatan analisis data terdiri dari tiga tahap yaitu: tahap pemeriksaan (editing), tahap pengkodean (coding) dan tahap tabulasi.

Analisis statistik deskriptif dimaksudkan untuk meringkas data penelitian guna memberikan gambaran yang lebih jelas agar mudah dipahami. Menurut Santosa dan Ashari (2005:19) ukuranukuran yang digunakan dalam statistik deskriptif meliputi: ukuran pemusatan (rata-rata, median, dan modus), ukuran penyebaran (varians, standar deviasi, dan range). Di samping itu, juga dilakukan analisis frekuensi yang berfungsi untuk memberikan gambaran sekilas dan ringkas (first look) dari sekelompok data (Santoso, 2006:133).

Data yang telah diperoleh diolah dan dianalisis dengan uji statistik inferensial. Uji statistik inferensial adalah teknik statistik yang berhubungan dengan analisis data guna menguji hipotesis (Santosa dan Ashari, 2005:2). Untuk menguji hipotesis digunakan teknik analisis statistik $t$ tes yang bertujuan untuk menguji perbedaan dua rata-rata dari dua sampel pada suatu variabel.

\section{Analisis dan Interpretasi}

Pelaksanaan penelitian di MAN Darussalam, Kabupaten Aceh Besar, Provinsi Nanggroe Aceh Darussalam, berlangsung selama dua bulan setengah dimulai tanggal 26 Januari 2008 sampai dengan 10 April 2008. Tahap pelaksanaan penelitian diawali dengan kegiatan sosialisasi pembelajaran kimia berbasis TI. Tahap ini merupakan bagian yang paling besar konsentrasinya baik dari segi waktu maupun tenaga. Karena keberhasilan dari penelitian ini sangat tergantung dari pemahaman siswa terhadap penggunaan media pembelajaran berbasis TI, khususnya komputer. Kebijakan ini ditempuh mengingat siswa MAN Darussalam belum pernah mendapatkan metode pembelajaran berbasis TI sebelumnya. Setelah siswa memahami dan dapat menggunakan media pembelajaran berbasis TI, khususnya memahami navigasi pembelajaran interaktif maka tahap sosialisasi dianggap telah memadai. Pada praktiknya tahap ini memakan waktu lebih kurang enam minggu. Sisa waktu selanjutnya digunakan untuk tahap pengumpulan dan pengolahan data penelitian. Kegiatan ini berlangsung selama lebih kurang empat minggu.

Penelitian ini melibatkan siswa-siswi MAN Darussalam yang terdiri dari tiga tingkatan kelas yaitu kelas X (X1-X4), kelas XI-IPA dan kelas XIIIPA, dengan jumlah sampel 184 siswa/responden. Siswa pada setiap kelasnya dikelompokkan ke dalam 2 kategori berdasarkan pola kelompok paralel yang ekuivalen, yaitu kelompok yang memiliki kemampuan yang sama (Bungin, 2005:146). Adapun kategori kedua kelompok tersebut adalah a) Kelompok eksperimen adalah kelompok siswa 
yang dikenakan variabel eksperimen yaitu media pembelajaran berbasis TI yang digunakan pada proses pembelajaran kimia dan b) Kelompok kontrol adalah kelompok siswa yang dikenakan pembelajaran kimia secara konvensional. Dari keseluruhan sampel (184 siswa) pada penelitian ini diperoleh 92 siswa dalam kategori kelompok eksperimen dan 92 siswa dalam kategori kelompok kontrol dengan rincian sebagai berikut:

Tabel 1. Data Pengelompokkan Siswa

\begin{tabular}{|c|c|c|c|}
\hline \multirow{2}{*}{ Kelas } & \multicolumn{2}{|c|}{ Kelompok } & \multirow{2}{*}{ Jumlah } \\
\cline { 2 - 3 } & Eksperimen & Kontrol & \\
\hline $\mathrm{X}$ & 60 & 60 & 120 \\
\hline $\mathrm{XI}$ & 14 & 14 & 28 \\
\hline $\mathrm{XII}$ & 18 & 18 & 36 \\
\hline Total & 92 & 92 & 184 \\
\hline
\end{tabular}

\section{Hasil Penelitian dan Pembahasan}

\section{Analisis Deskriptif Identitas Responden}

Berikut adalah bahasan analisis deskriptif identitas responden yang dikategorikan menurut Jenis Kelamin dan Kelas. Analisis ini memberikan gambaran umum dari responden. Perbandingan jenis kelamin responden adalah $32,6 \%$ laki-laki dan $67,4 \%$ perempuan. Perbandingan sedemikian rupa sebenarnya terjadi dengan sendirinya karena pembagian kelompok pada penelitian ini tidak didasarkan pada jenis kelamin, tapi pada ranking/ peringkat siswa di kelas.

Perbandingan jumlah siswa pada setiap tingkatan kelas adalah kelas X $65,2 \%$, kelas XI $15,2 \%$ dan kelas XII 19,6\%. Tidak berimbangnya pambagian jumlah siswa ini dikarenakan pada tingkatan kelas XI dan XII telah dilakukan penjurusan sehingga hanya kelas jurusan IPA (masingmasing terdiri dari satu kelas) yang dapat diambil sebagai sampel penelitian. Kelas $X$ merupakan kelas paralel dan untuk mencukupi jumlah sampel yang dibutuhkan maka seluruh siswa kelas $X$ dijadikan sampel.

Dari jawaban hasil tes yang diberikan kepada siswa setelah melakukan proses pembelajaran kimia diperoleh data primer hasil belajar siswa. Data hasil belajar siswa untuk masing-masing kelompok tersaji pada Tabel IV-2.
Tabel 2. Data Hasil Belajar Siswa

\begin{tabular}{|c|c|c|c|c|c|c|c|}
\hline \multirow[b]{2}{*}{ No } & \multirow[b]{2}{*}{ Kelas } & \multicolumn{2}{|c|}{ Nilai Kimia } & \multirow[b]{2}{*}{ No } & \multirow[b]{2}{*}{ Kelas } & \multicolumn{2}{|c|}{ Nilai Kimia } \\
\hline & & $\begin{array}{l}\text { Ekspe- } \\
\text { rimen }\end{array}$ & $\begin{array}{c}\text { Kon- } \\
\text { trol }\end{array}$ & & & $\begin{array}{l}\text { Ekspe- } \\
\text { rimen }\end{array}$ & $\begin{array}{c}\text { Kon- } \\
\text { trol }\end{array}$ \\
\hline 1 & $X$ & 85 & 43 & 47 & $X$ & 92 & 57 \\
\hline 2 & $X$ & 87 & 22 & 48 & $X$ & 92 & 57 \\
\hline 3 & $X$ & 87 & 57 & 49 & $X$ & 92 & 78 \\
\hline 4 & $X$ & 85 & 78 & 50 & $X$ & 83 & 63 \\
\hline 5 & $X$ & 93 & 70 & 51 & $x$ & 93 & 57 \\
\hline 6 & $X$ & 92 & 57 & 52 & $x$ & 87 & 57 \\
\hline 7 & $X$ & 87 & 57 & 53 & $\mathrm{X}$ & 87 & 70 \\
\hline 8 & $X$ & 87 & 57 & 54 & $x$ & 92 & 57 \\
\hline 9 & $X$ & 83 & 87 & 55 & $x$ & 92 & 72 \\
\hline 10 & $x$ & 83 & 43 & 56 & $x$ & 83 & 57 \\
\hline 11 & $X$ & 92 & 78 & 57 & $X$ & 92 & 57 \\
\hline 12 & $X$ & 87 & 57 & 58 & $X$ & 87 & 72 \\
\hline 13 & $X$ & 100 & 65 & 59 & $X$ & 100 & 72 \\
\hline 14 & $x$ & 87 & 63 & 60 & $x$ & 93 & 35 \\
\hline 15 & $x$ & 87 & 78 & 61 & XI & 80 & 60 \\
\hline 16 & $X$ & 85 & 63 & 62 & XI & 87 & 33 \\
\hline 17 & $X$ & 80 & 63 & 63 & XI & 90 & 63 \\
\hline 18 & $X$ & 85 & 35 & 64 & XI & 83 & 60 \\
\hline 19 & $x$ & 87 & 63 & 65 & XI & 90 & 43 \\
\hline 20 & $X$ & 92 & 78 & 66 & XI & 100 & 77 \\
\hline 21 & $x$ & 87 & 57 & 67 & XI & 87 & 67 \\
\hline 22 & $X$ & 100 & 57 & 68 & XI & 87 & 67 \\
\hline 23 & $X$ & 85 & 65 & 69 & XI & 90 & 70 \\
\hline 24 & $x$ & 100 & 78 & 70 & XI & 90 & 43 \\
\hline 25 & $x$ & 93 & 63 & 71 & XI & 90 & 100 \\
\hline 26 & $x$ & 87 & 78 & 72 & XI & 87 & 60 \\
\hline 27 & $x$ & 87 & 57 & 73 & XI & 90 & 60 \\
\hline 28 & $x$ & 87 & 57 & 74 & XI & 93 & 60 \\
\hline 29 & $x$ & 93 & 72 & 75 & XII & 92 & 62 \\
\hline 30 & $X$ & 87 & 65 & 76 & XII & 87 & 47 \\
\hline 31 & $X$ & 83 & 85 & 77 & XII & 100 & 62 \\
\hline 32 & $X$ & 93 & 78 & 78 & XII & 87 & 40 \\
\hline 33 & $x$ & 83 & 43 & 79 & XII & 87 & 40 \\
\hline 34 & $X$ & 93 & 78 & 80 & XII & 92 & 62 \\
\hline 35 & $x$ & 92 & 63 & 81 & XII & 87 & 77 \\
\hline 36 & $x$ & 85 & 78 & 82 & XII & 87 & 47 \\
\hline 37 & $x$ & 93 & 63 & 83 & XII & 87 & 62 \\
\hline 38 & $X$ & 85 & 57 & 84 & XII & 92 & 77 \\
\hline 39 & $X$ & 93 & 57 & 85 & XII & 83 & 55 \\
\hline 40 & $x$ & 80 & 65 & 86 & XII & 100 & 68 \\
\hline 41 & $x$ & 92 & 78 & 87 & XII & 87 & 53 \\
\hline 42 & $X$ & 93 & 50 & 88 & XII & 93 & 63 \\
\hline 43 & $x$ & 83 & 78 & 89 & XII & 87 & 60 \\
\hline 44 & $x$ & 87 & 63 & 90 & XII & 83 & 62 \\
\hline 45 & $x$ & 92 & 72 & 91 & XII & 92 & 47 \\
\hline 46 & $x$ & 93 & 78 & 92 & XII & 92 & 53 \\
\hline
\end{tabular}

Data hasil belajar siswa yang diperoleh pada penelitian ini menunjukkan perbedaan yang mencolok pada kedua kelompok. Perolehan nilai yang tinggi dari kelompok eksperimen disebabkan oleh beberapa hal, di antaranya karena penggunaan media pembelajaran yang baru dikenal akan sangat menarik bagi siswa sehingga menimbulkan rasa ingin tahu (curiosity) yang sangat besar pada diri siswa. Hal ini sejalan dengan pendapat Koesnandar (2003) yang menyatakan bahwa, "Media yang lebih baru biasanya lebih baik dan lebih menarik bagi siswa." 
Di samping itu, hasil belajar siswa yang tinggi ini karena program pembelajaran interaktif yang diberikan dirancang secara sederhana sehingga siswa dapat memahami dan menguasai navigasi dengan mudah. Menurut Ena (2000:3), sebuah program yang dirancang secara sederhana dengan navigasi yang mudah memungkinkan siswa tidak perlu belajar komputer lebih dahulu untuk dapat menggunakannya sebagai media pembelajaran interaktif. Selanjutnya, hasil ini akibat media pembelajaran interaktif mampu menyajikan informasi yang dapat diulang-ulang sesuai keperluan dan kecepatan respon siswa (Sutisna, 2005).

Nilai kelompok kontrol yang berbeda jauh dari nilai kelompok eksperimen disebabkan karena faktor psikologis siswa, di mana siswa yang termasuk dalam kelompok kontrol pada umumnya merasa kecewa karena tidak terpilih dalam kelompok eksperimen. Di samping itu, pembelajaran konvensional mempunyai beberapa kelemahan seperti penyampaian materi pelajaran sangat tergantung dari kemampuan guru. Dalam penyajian materi pelajaran terdapat kemungkinan adanya materi yang terlewatkan dan sering terjadi penekanan yang berlebih di satu bagian sementara bagian yang lain hanya dijelaskan seadanya. Pembelajaran konvensional bersifat monoton dan sangat membosankan bagi siswa sehingga mengurangi motivasi dan kreativitas siswa yang berakibat pada pencapaian hasil belajar yang relatif rendah (Sudjana, 2001: 40).

Temuan data hasil belajar siswa ini menunjukkan hasil yang berbeda pada siswa yang menggunakan media pembelajaran berbasis TI dengan pembelajaran secara konvensional. Kemudian dilakukan uji statistik untuk membuktikan apakah memang benar terdapat perbedaan hasil belajar siswa yang menggunakan media pembelajaran berbasis TI dalam proses pembelajaran kimia dengan hasil belajar siswa secara konvensional. Uji statistik ini dimaksudkan untuk mengetahui apakah perbedaan yang terdapat pada dua sampel tersebut benar-benar meyakinkan atau karena semata-mata kesalahan dalam pengambilan sampel atau kesalahan menggunakan teknik sampling semata (Soedjarnarto, 1989:41).

\section{Analisis Statistik Inferensial}

Analisis statistik inferensial adalah teknik statistik yang berhubungan dengan analisis data (Santosa, 2005:2). Analisis data ini dimaksudkan untuk melakukan uji terhadap hipotesis. Adapun hasil analisis statistik inferensial terhadap hipotesis pada penelitian disajikan berikut ini.

Uji Hipotesis pada penelitian ini adalah sebagai berikut.

$\mathbf{H}_{\mathbf{0}}$ : Tidak ada perbedaan hasil belajar siswa yang menggunakan media pembelajaran berbasis TI dalam proses pembelajaran kimia dengan hasil belajar siswa pada proses pembelajaran kimia secara konvensional.

$\mathbf{H}_{1}$ : Ada perbedaan hasil belajar siswa yang menggunakan media pembelajaran berbasis TI dalam proses pembelajaran kimia dengan hasil belajar siswa pada proses pembelajaran kimia secara konvensional.

Untuk menguji hipotesis ini dibutuhkan data primer hasil belajar siswa untuk kedua kelompok (Tabel IV-2: Data Hasil Belajar Siswa). Tabel IV-3 mendeskripsikan ringkasan statistik dari kedua sampel yang masing-masing terdiri dari 92 siswa.

Tabel 3: Deskripsi Mata Pelajaran Kimia

\begin{tabular}{|c|c|c|c|c|}
\hline $\begin{array}{c}\text { Mata } \\
\text { Pela- } \\
\text { jaran }\end{array}$ & $\begin{array}{c}\text { Metode } \\
\text { Pembe- } \\
\text { lajaran }\end{array}$ & $\begin{array}{c}\text { Jumlah } \\
\text { Sampel }\end{array}$ & $\begin{array}{c}\text { Rata- } \\
\text { Rata }\end{array}$ & $\begin{array}{c}\text { Standar } \\
\text { Deviasi }\end{array}$ \\
\hline Kimia & Berbasis TI & 92 & 89,06 & 4,748 \\
\cline { 2 - 5 } & $\begin{array}{c}\text { Konven- } \\
\text { sional }\end{array}$ & 92 & 62,05 & 13,133 \\
\hline
\end{tabular}

Dari Tabel IV-3 terlihat hasil belajar kimia berbasis TI mempunyai nilai rata-rata 89,06, yang jauh di atas nilai rata-rata hasil belajar kimia secara konvensional yaitu 62,05. Adapun standar deviasi untuk hasil belajar kimia berbasis TI adalah 4,748 sedangkan hasil belajar kimia secara konvensional memiliki standar deviasi yang lebih besar yaitu 13,133.

Grafik IV-1 menunjukkan perbedaan rata-rata hasil belajar kimia berbasis TI dengan hasil belajar kimia secara konvensional. Selanjutnya, kedua rata-rata ini akan diuji dengan menggunakan uji statistik $\mathrm{t}$ tes untuk mengetahui apakah kedua rata-rata tersebut benar-benar berbeda atau perbedaannya hanya disebabkan semata-mata 
Grafik Rata-Rata Mata Pelajaran Kimia

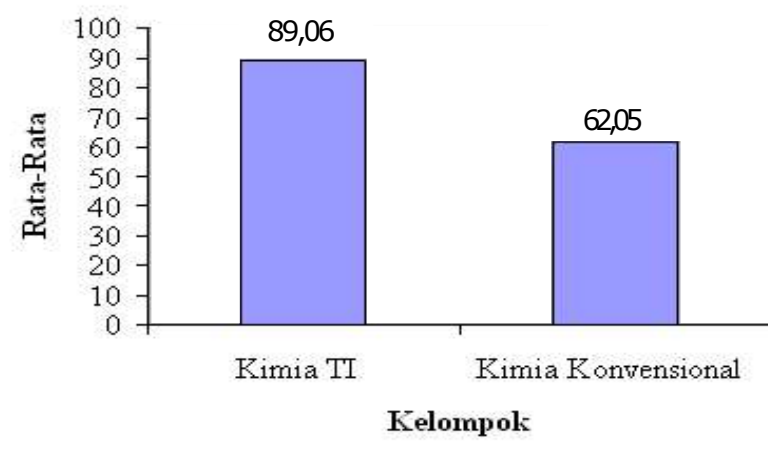

Grafik 1: Rata-Rata Mata Pelajaran Kimia

karena kesalahan dalam pengambilan sampel atau kesalahan menggunakan teknik sampling (Soedjarnarto, 1989:41).

Adapun statistik $\mathrm{t}$ tes yang digunakan adalah Independent Sample Test yang bertujuan untuk menguji apakah ada perbedaan rata-rata dari kedua sampel pada satu variabel (Santoso, 2006:195). Tabel IV-4 menampilkan hasil uji statistik t-tes yang dilakukan dengan maksud untuk mengetahui ada tidaknya perbedaan ratarata dari hasil belajar kimia dengan menggunakan media pembelajaran berbasis TI dengan pembelajaran kimia secara konvensional.

\section{Uji Perbedaan Rata-Rata}

Hipotesis untuk pengujian rata-rata.

$\mathrm{H}_{0}$ : Rata-rata hasil belajar kimia berbasis TI dan rata-rata hasil belajar kimia secara konvensional adalah identik.

$\mathrm{H}_{1}$ : Rata-rata hasil belajar kimia berbasis TI dan rata-rata hasil belajar kimia secara konvensional adalah tidak identik.

Untuk menguji hipotesis ini digunakan uji dua sisi yang bertujuan untuk melihat "berbeda" atau "tidak berbeda".

Tabel 4: Analisis t tes Mata Pelajaran Kimia

\begin{tabular}{|c|c|c|c|c|}
\hline $\begin{array}{l}\text { Mata } \\
\text { Pela- } \\
\text { jaran }\end{array}$ & T hitung & $\begin{array}{c}\text { Signifi- } \\
\text { kansi }\end{array}$ & T tabel & $\begin{array}{c}\text { Signifi } \\
\text { kansi }\end{array}$ \\
\hline Kimia & 18,552 &, 000 & 1,986 & $\begin{array}{c}0,05 \\
(\alpha=5 \%)\end{array}$ \\
\hline
\end{tabular}

Dari Tabel 4 terlihat bahwa t hitung untuk rata-rata hasil belajar kimia adalah 18,552 dengan signifikansi 0,000. Hasil t hitung di atas dibandingkan dengan $\mathrm{t}$ tabel. Nilai $\mathrm{t}$ tabel pada penelitian ini adalah sebesar 1,986. Hal ini didasarkan pada signifikansi ( $\alpha=5 \%$ ) dan derajat kebebasan (degree of freedom/df) $91(n-1)$. Oleh karena signifikansi untuk uji dua sisi $(0,000 / 2=0,000)<$ 0,025 maka $\mathrm{H}_{0}$ ditolak atau kedua rata-rata (mean) hasil belajar kimia menggunakan media pembelajaran berbasis TI dengan pembelajaran kimia secara konvensional benar-benar berbeda signifikan (nyata), dalam artian hasil belajar kimia menggunakan media pembelajaran berbasis TI mempunyai rata-rata lebih tinggi dari pembelajaran kimia secara konvensional. Dengan kata lain, terdapat perbedaan hasil belajar siswa yang menggunakan media pembelajaran berbasis TI dengan hasil belajar siswa secara konvensional.

Untuk uji hipotesis ini dapat disimpulkan bahwa terdapat perbedaan nyata/signifikan secara statistik antara hasil belajar siswa yang menggunakan media pembelajaran berbasis TI dalam proses pembelajaran kimia dengan hasil belajar siswa pada proses pembelajaran kimia secara konvensional (Ho ditolak dan $\mathrm{H}_{1}$ diterima).

\section{Interpretasi Hasil Uji Hipotesis}

Hasil uji hipotesis dengan menggunakan analisis statistik $\mathrm{t}$ tes menunjukkan adanya perbedaan nyata antara hasil belajar siswa yang menggunakan media pembelajaran berbasis TI dalam proses pembelajaran kimia dengan hasil belajar siswa pada proses pembelajaran kimia secara konvensional.

Dari hasil ini dapat diinterpretasikan bahwa tingginya hasil belajar siswa yang menggunakan media pembelajaran berbasis TI disebabkan kemampuan media tersebut dalam menyajikan materi pembelajaran secara nyata dan menarik serta dapat dilakukan berulang-ulang (tetap konsisten) sampai siswa memahami materi yang disajikan.

Temuan ini sesuai dengan pernyataan Pribadi (2004:148) dan Sutisna (2005), yaitu media pembelajaran berbasis TI (komputer) memungkinkan siswa belajar sesuai dengan kemampuan dan kecepatannya dalam memahami pengetahuan dan informasi yang ditayangkan. Hal ini dikarenakan media tersebut mampu menyajikan informasi yang dapat diulang-ulang sesuai keperluan dan 
kecepatan respon siswa. Selain itu, komputer dapat digunakan sebagai sarana untuk melakukan kegiatan belajar yang bersifat simulasi karena memiliki kemampuan dalam mengintegrasikan komponen warna, suara dan animasi grafik (graphic animation), sehingga mampu menyampaikan informasi dan pengetahuan secara lebih nyata. Tisnoherawati (2005:41) menambahkan ada faktor lain yang mempengaruhi peningkatan hasil belajar di antaranya interaksi siswa dalam pembelajaran sangat dipengaruhi oleh kondisi siswa maupun kondisi dan situasi proses pembelajaran itu sendiri.

Dari hasil uji hipotesis yang diperoleh melalui berbagai analisis statistik di atas dapat dinyatakan bahwa penggunaan media pembelajaran berbasis TI dalam proses pembelajaran dapat memberi pengaruh nyata terhadap peningkatan hasil belajar siswa. Hal ini sejalan dengan beberapa hasil penelitian terdahulu baik di dalam maupun di luar negeri yang memanfaatkan TI dalam proses pembelajaran di antaranya penelitian Anne L. Rantie dkk. yang melakukan eksperimen mengenai pemanfaatan TI untuk mendukung kegiatan belajar mengajar Bahasa Inggris di SMU 1 BPK Penabur Jakarta, penelitian yang dilakukan oleh Center for Applied Special Technology (CAST), penelitian di SMP Christopher New Jersey, dan penelitian di SMU Lester B. Pearson Kanada, yang kesemuanya menunjukkan bahwa pemanfaatan TI dalam proses pembelajaran dapat meningkatkan hasil belajar siswa.

Hasil penelitian ini membuktikan bahwa pemanfaatan TI dalam proses pembelajaran mampu menjadikan pembelajaran lebih efektif yang ditandai dengan adanya peningkatan hasil belajar siswa. Dengan demikian, diharapkan hasil penelitian ini dapat memberi masukan dan menjadi pemicu bagi semua pihak terkait untuk segera menerapkan pembelajaran berbasis TI guna meningkatkan hasil belajar siswa yang akan berdampak terhadap peningkatan kualitas pendidikan.

\section{Simpulan dan Saran Simpulan}

Simpulan diperoleh berdasarkan hasil analisis data dan bahasan serta kajian pustaka dan tinjauan studi yang telah dibahas terdahulu. Adapun simpulan yang diperoleh pada penelitian ini.
Media pembelajaran berbasis TI memungkinkan siswa belajar sesuai dengan kemampuan dan kecepatannya dalam memahami pengetahuan dan informasi karena dapat dilakukan berulangulang (tetap konsisten) sampai siswa memahami materi yang disajikan.

Media pembelajaran berbasis TI dapat digunakan sebagai sarana untuk melakukan kegiatan belajar yang bersifat simulasi karena memiliki kemampuan dalam mengintegrasikan komponen warna, suara dan animasi grafik (graphic animation), sehingga mampu menyampaikan informasi dan pengetahuan secara lebih nyata.

Dari hasil penelitian, penggunaan media pembelajaran berbasis TI dalam proses pembelajaran kimia dapat meningkatkan hasil belajar siswa, dimana ada perbedaan yang signifikan antara hasil belajar siswa yang menggunakan media pembelajaran berbasis TI dalam proses pembelajaran dengan hasil belajar siswa pada proses pembelajaran secara konvensional.

\section{Saran}

Hasil penelitian menunjukkan adanya hubungan yang signifikan antara pemanfaatan TI dalam proses pembelajaran kimia terhadap peningkatan hasil belajar siswa. Berdasarkan simpulan dari penelitian ini, ada lima saran yang disampaikan.

Pertama, guru mata pelajaran kimia supaya dapat menerapkan pembelajaran dengan menggunakan media pembelajaran berbasis TI dalam upaya meningkatkan hasil belajar siswa, di samping menciptakan sumber daya manusia yang tidak gagap teknologi. Kedua, kepala madrasah/sekolah sebagai pengelola, motivator dan supervisor pembelajaran di madrasah/ sekolah yang dipimpinnya perlu membantu mensosialisasikan temuan penelitian ini dengan cara (i) membuat kebijakan di tingkat madrasah/ sekolah untuk menerapkan hasil penelitian ini; (ii) mengadakan seminar dan lokakarya yang terkait dengan temuan penelitian ini; dan (iii) mengadakan pelatihan pengembangan model pembelajaran dengan menggunakan media pembelajaran berbasis TI untuk berbagai mata pelajaran. Ketiga, kepada siswa disarankan untuk dapat memanfaatkan media pembelajaran berbasis TI secara mandiri (self learning), tidak hanya materi 
pembelajaran yang tersedia di madrasah/sekolah melainkan dapat di download dari berbagai media lainnya seperti internet. Keempat, kepada Pemerintah/Instansi terkait diharapkan hasil penelitian ini dapat disebarluaskan kepada madrasah/sekolah lainnya dan segera memfasilitasi kebutuhan TI bagi penyelenggaraan proses pembelajaran di madrasah/sekolah guna meningkatkan mutu pendidikan. Kelima, mengamati besarnya pengaruh penggunaan media pembelajaran berbasis TI terhadap peningkatan hasil belajar siswa, diharapkan hasil penelitian ini sebagai rujukan bagi pengembangan penelitian lanjutan. Adapun penelitian lanjutan yang dapat dilakukan antara lain: (i) Meneliti tingkat konsistensi hasil belajar pada siswa yang menggunakan media pembelajaran berbasis TI; (ii) Melakukan penelitian dengan jumlah sampel yang lebih besar; (iii) Melakukan penelitian dengan mata pelajaran lain seperti mata pelajaran Sosial, Ekonomi dan Bahasa; dan (iii) Melakukan penelitian pada jenjang pendidikan lainnya seperti MI/SD dan MTs/SMP bahkan di Perguruan Tinggi.

\section{Pustaka Acuan}

Bungin, B. 2005. Metodologi Penelitian Kuantitatif. Jakarta:Kencana

Ena, Ouda T. 2000. Membuat Media Pembelajaran Interaktif Dengan Piranti Lunak Presentasi. www.ialf.edu. (Diakses 1 April 2008).

Hardjito. 2004. Internet Untuk Pembelajaran. www.pustekkom.go.id. (Diakses 13 Maret 2008). http://lib.balaibahasa.org//viewdeetailphp?id=8975

Koesnandar, A. 2003. Guru dan Media Pembelajaran. www.pustekkom.go.id. (Diakses 1 April 2008).

Ma'arif, A. S. Fajar., A, Achmad, A, Pratiknya AW. Karim. M.R. dan Soeroyo, 1991. Pendidikan di Indonesia antara Cita dan Fakta, Yogyakarta:Tiara Wacana.

Nugroho, Lukito E. 2005. Model Open Source dan Pembelajaran TI di Sekolah Menengah di Indonesia. www.mti.ugm.ac.id. (Diakses 3 April 2008).

Pribadi, Benny A. 2004. Ketersediaan dan Pemanfaatan Media dan Teknologi Pembelajaran di Perguruan Tinggi, Jurnal Pendidikan; (5)2:146-148.

Riyanto, G. 2006. Teknologi Informasi, Inovasi Bagi Dunia Pendidikan. www.jurnal-Kopertis4.org. (Diakses 3 April 2008).

Santosa, Purbayu B., dan Ashari. 2005. Analisis Statistik Dengan Microsoft Excel \& SPSS. Yogyakarta:Andi.

Santoso, S. 2006. Menguasai Statistik di Era Informasi Dengan SPSS 14.Jakarta: Elex Media Komputindo.

Soedjarnarto. 1989. Statistik Inferensial. Surabaya: IKIP Negeri Surabaya.

Sudjana, N. 2001. Penilaian Hasil Proses Belajar Mengajar. Bandung:Remaja.

Sutisna, E. 2005. Pemanfaatan Teknologi Informasi dalam Pembelajaran. www.bantencerdas.net. (Diakses 12 Februari 2008).

Tisnoherawati, N. 2005. Pengaruh Penggunaan Peralatan KIT IPA Dalam Pembelajaran IPA Terhadap Prestasi Belajar IPA Siswa SD Negeri di Kecamatan Purworejo Kota Pasuruan Jawa Timur. www.damandiri.or.id. (Diakses 12 Februari 2008). 